The National Library supplies copies of this article under licence from the Copyright Agency Limited (CAL). Further reproductions of this article can only be made under licence.

\title{
Fading to Black: Aboriginal Children in Colonial Texts
}

\author{
Clare Bradford
}

I Charles Kingsley's The Water-Babies, Tom, the chimney-sweep, is set to work cleaning the chimneys of Sir John Harthover. He climbs down the wrong chimney to find himself in a bedroom 'all dressed in white', that of Ellie, the young daughter of the house. This is what he sees:

And looking round, he suddenly saw, standing close to him, a little ugly, black, ragged figure, with bleared eyes and grinning white teeth. $\mathrm{He}$ turned on it angrily. What did such a little black ape want in that sweet young lady's room? And behold, it was himself reflected in agreat mirror...

Tom's sudden vision of the 'little black ape' comprises a kind of doubletake: his first reading of the figure sees it as the Other of his self; black to his white; ape to his human. Then, peering into the mirror, he realises that he sees a self strangely mixed with the Other, black exterior concealing whiteness, and it's this view which motivates his frantic attempts to clean himself, during the course of which he falls into a river, drowns and becomes a waterbaby. I'll argue that for the white child readers interpellated by colonial texts, Aboriginal child characters similarly invoke a kind of doubletake: first, the shock of Otherness displayed in Tom's reaction; and secondly, a much more ambiguous and threatening possibility: that of a mixing or hybridisation of identities.

Questions of boundaries are fundamental in colonial representations of Aboriginal children, because white child readers are positioned to read these figures as lessons about the boundaries between self and Other; boundaries which originate in oppositions between white and black and which incorporate a set of associated binaries: for example, between rationality and instinct; culture and nature; religion and savagery. Aboriginal children in these texts are related to a figure central to Bakhtin's treatment of carnival and the carnivalesque, that of the grotesque, described by Stallybrass and White as incorporating two models: "the grotesque [as] simply the opposite of the classical'; and the grotesque 'formed through a process of hybridization or inmixing of binary opposites' (1986, p.44).
James Donald locates the grotesque in colonial discourse, spelling out its dual form. The first grotesque, he says, is "the grotesque as the "Other" of the defining group or self" (1988, p.36): Tom's first vision of the 'little black ape'. The 'second, hybrid grotesque' is produced 'by the very struggle to exclude the first grotesque'. and arises from 'the ... attempt to demarcate boundaries' (p.37). In children's texts the anxiety evoked by such hybridisation is projected onto Aboriginal child characters who lean in the direction of whiteness, either by conversion to Christianity or because they align themselves with Europeans or because they are children of mixed race. Aboriginal children represented as hybrid grotesques are commonly treated by way of allusion and symbol, and seem always in danger of death, a drastic narrative closure which serves to reassure white child readers.as to the stability of an Australian nationalism reliant on Englishness.

While most nineteenth-century texts set in Australia were published in Britain, they vary in the circumstances of their production. Adventure novels by writers such as W.H.G. Kingston and George Manville Fenn form part of a body of imperial texts produced by British writers with no personal experience of Australia, who relied for local colour on travellers' tales and descriptions of Australian flora and fauna, and whose repertoire included adventure novels set throughout the Empire. But many texts were produced by settlers or by writers who lived in Australia, or who moved back and forth between Australia and Britain, and these texts bear the marks of 'that neither/nor territory of white settler-colonial writing which Alan Lawson has called the "Second World"' (Slemon 1995, p.104). Unlike Kingston and Fenn, who wrote from the imperial centre, colonial children's writers, while publishing in Britain for a combined audience of British and Australian children, produced their novels 'in a place of ambivalence: between systems, between discursive worlds, implicit and complicit in both of them' (Slemon, p. 108).

Whether produced in the imperial centre or at its margins, children's texts set in Australia constituted part of a set of socialising practices which sought to form young people as citizens of the British Empire. British child readers were positioned to understand them as exemplifications of a metanarrative of imperial expansion, realised through 
stories in which boy heroes (in the case of novels of adventure and settlement) overcame a formulaic set of trials, generally involving venomoūs snakes, encounters with hostile Aborigines, bushfires, floods, conflict with bushrangers and being lost in the bush, which encoded the exotic and constituted rites of passage from childhood to adulthood, and from imperial centre to colonial margins. The smaller audience of Australian child readers were positioned as British and imperial subjects, but also as young colonisers and (increasingly throughout the nineteenth century) as Australian citizens. During this period children's books came to be marketed along gender lines, with stories of adventure and settlement featuring male protagonists and implying boy readers, and stories of domestic life concentrating on stereotypically feminine concems. Most of my textual examples are taken from adventure novels, but I will draw also on the first Australian-published children's book, $A$ Mother's Offering to Her Children (1841), and on two late nineteenth-century Aboriginalist texts.

In 'The Order of Discourse', Foucault identifies three procedures by which societies control the production of discourse: prohibition; the distinction between reason and madness; the opposition between true and false. The 'will to truth', Foucault says, 'rests on an institutional support', (in Rice and Waugh 1989, p.242), for it works within social practices and institutions such as those of pedagogy, religion, law and publishing; and it exerts pressure on the discourses of these institutions by assimilating them into its universalising frame. For what is at stake is the survival and stability of such institutions, or, to use Foucault's phrase, 'desire and power' (p.243). Of all categories of literary production, children's texts constitute a most striking example of the workings of Foucault's 'will to truth', because they are written to and for readers who do not yet know (or who only partly know) the truths of the institutions within which they live; readers on whom (once they cease to be children) these very institutions will depend for their maintenance and good health.

My purpose in this paper, then, is to identify how the will to truth manifests through the discursive and narrative strategies involved in representations of Aboriginal children in nineteenth-century children's texts; and what these representations have to say about 'the constitution of the Aboriginal subject' (Attwood 1992, p.ii). Hodge and Mishra note that Aborigines have always been 'important to White Australians out of all proportion to their numbers' because 'they have always been "goods to think with", to use Lévi-Strauss's graphic phrase' (1990, p.52). In the books I discuss there are relatively few Aboriginal child characters, but the 'ideological work' (Hodge and Mishra, p.52) to which they are put is of great significance in its construction of Aboriginality and its positioning of child readers.

Sally, the first Aboriginal child represented in Australianpublished children's literature, features in Charlotte Barton's A Mother's Offering to her Children by a Lady Long Resident in New South Wales (1841). The chapter entitled 'Anecdotes of the Aborigines of New South Wales' opens with the following words: 'Little Sally the black child has been accidentally killed' (p.197). A Mother's Offering is framed as a series of conversations between Mrs Saville, and her four children, and Emma Saville puts a question which leads to an account of the context of Sally's death:

$$
\begin{aligned}
& \text { Emma.- Do you not think her mother will be very } \\
& \text { sorry, when she hears of it? } \\
& \text { Mrs. S. - Alas! my dear children, her mother also } \\
& \text { met with an untimely death. } \\
& \text { These poor uncivilized people, most frequently } \\
& \text { meet with some deplorable end } \\
& \text { through giving way to unrestrained passions. } \\
& \text { (p.197) }
\end{aligned}
$$

The 'unrestrained passions' which are at question in these two deaths are specifically sexual passions, for Sally is the child of an Aboriginal mother and a white father, and is therefore an example of that dangerous hybridisation which threatens racial purity. Charlotte Barton's predicament is to warn child readers of the dangers of Aboriginal sexuality while observing a seemly reticence about the body. Various textual signals disclose the gaps between what Mrs Saville says and what implied readers are to deduce; for example, the child Sally is described by one of the Saville children as 'a pretty, fat, little brown 
girl' (p.198), but Mrs Saville offers the orthodox term: 'The child was a half-cast [sic]' (p.199). In a euphemism designed at once to conceal and to disclose, Sally's mother is characterised as 'particularly fond' of 'living among white people', and it's said to be because of the 'great objection' that Aborigines have to this practice that she has been killed by her half-brother (p.209). Promiscuity and sexual jealousy are thus attributed, respectively, to Aboriginal women and men, while white men are situated outside the narrative, innocent objects of the lust of Aboriginal women. I read the story of Sally as a cautionary tale about miscegenation, directed at implied child readers who include boys as well as girls, for the narratees of Mrs Saville's stories are her son and three daughters, and the book's accounts of shipwrecks, settlement, mining and descriptions of Australian flora and fauna are clearly intended for a mixed audience.

Sally is not only a child of mixed race; she's also a stolen child, 'adopted' at two by a young white woman. The ambivalence of the text is especially noticeable in its treatment of Sally's status as a child living between cultures. She's depicted as inconsolable at being removed from her mother; her mother, on the other hand, 'whip [s] her severely' (p.201) when Sally wishes to stay with her. A nineteenth-century text directed at children can scarcely represent a child so unnatural or so vicious as to wish to leave her mother; but the figure of the unnatural Aboriginal mother is set against that of the good white mother who tells the story, and the Saville children model for the book's readers the white child's horror:

Emma. - Oh! Mamma, this is too shocking! to leave her little child among strangers; and then whip it for being so glad to see her again; and for wishing to go with her...I wish you had taken it from such a bad mother; and then we would have done all we could to have made it forget, it ever had such a naughty, cruel mother.

(p.201)

Sally's death is accidental (she is crushed by a beam of wood), but in incorporating her story with that of her mother, the text treats her death as natural, an outcome to be expected given the 'unrestrained passions' which are written into the figures of mother and child.
In Mrs H. Scholefield's Short Memoir of William Wimmera (1853), published in England and serialised in the Melbourne Church of England Messenger during 1854, the death of an Aboriginal child is afforded an idealised and exemplary treatment. The Memoir is written in a hagiographical mode and features the short life and saintly death of an Aboriginal boy, William Wimmera; who is, like Sally, a stolen child. William is described as the orphaned son of 'parents of the Wimmera tribe' (p.9), and at the age of ten he is discovered, living on the streets of Melbourne, by a clergyman, $\mathrm{Mr}$ Chase, who 'adopts' him and takes him to England:

When it was fixed for Mr. Chase's return to England, it struck him, that could this child be entirely separated from old associations, and brought to England to receive a Christian education, he might, by God's blessing, hereafter return to Australia and teach his poor benighted people.

(p.12)

The term 'benighted' is especially apt as a representation of Aboriginality in this text, because William's journey from Australia to England is inserted into a metanarrative of pilgrimage from the darkness of savagery to the light of evangelical Christianity, as the conclusion of the narrative makes clear:

... we have traced the history of this infant pilgrim, from the wilds of Australia to the pastures of the heavenly Canaan, where we trust he is feeding beside the living waters.

And let us see what lesson of real instruction can be gathered from it. His life was short, but of deep interest. Indeed, it may be said, that it was only the last year of that short life in which he began to live; for while in heathen darkness he was little better than the animals around him. One of his dying expressions was, 'No God in the bush', and, 'If I die there. I go to hell.'

(pp.40-41)

The focus of the text is not so much on William's conversion as on Mr Chase's strenuous efforts to convert him. During the voyage to England his mentor instructs 
him in reading and writing, though only a little each day so as not to 'overstrain his untaught mind' (p.13), teaching him the Lord's prayer and providing him with a simple catechism containing 'all the most important truths of the Christian faith' (p.15). Williarn's untaught mind, a true tabula rasa, is remarkably apt at remembering the pictures he sees and the stories he hears; at the same time, the text's emphasis on his difficulties in reading, and on his facility with practical skills such as plaiting straw and making shoes, constructs William's intelligence as inferior to that of the book's readers and places him at the lower end of the British class system; additionally, representations of his pidgin English fix him as eternal child and primitive.

It's when William contracts the 'congestion of the lungs' which kills him that 'the good seed which had been prayerfully sown in the dear child's heart, began to spring up' (p.19), and around half the narrative is taken up with descriptions of William's 'great interest in divine things', manifested in his edifying sickbed conversations and his account of a dream in which he enters heaven and meets Jesus. William's death, unlike that of Little Nell, is not eroticised (see Kincaid, 1992, pp.238-240); it's his soul, not his body, on which the text is focused. The fact of his Aboriginality comprises a test-case for the power of evangelism, so that his function as 'goods to think with' is to demonstrate that even the Other can be saved; and to persuade child readers of the value of missionary activity. At the same time, death is the only imaginable ending for William's story, because the religious discourses which shape it are so unequivocal in their identification of blackness with sin as to problematise the very idea of his survival.

I've said that relatively few Aboriginal children feature in colonial children's texts; more than this, there's a marked absence of Aboriginal child characters even in settings in which one might expect to find them; for example, within the captivity narratives which feature in many adventure novels, during which white boys are captured by Aborigines and live among them - sometimes for considerable periods of time - there are few references to Aboriginal children except as homogenised and undifferentiated figures. One explanation for such absence can be deduced from an illustration (Plate 1) from Edward
Rowe's The Boy in the Bush (1869), in which the boy adventurers Harry and Donald watch a corroboree, unseen by the Aborigines who participate in it. The reader, whose viewpoint takes in the boys and what they see, is positioned to compare the two sets of figures. The solid, sturdy forms of Harry and Donald, the play of light on their faces and upper bodies and their stance as they clutch each other for support, construct them both as 'little men' and as innocents abroad. They focalise for child readers the view of the corroboree towards which Harry looks, a view framed by twisted tree-trunks and by foliage which inscribe the Aborigines as grotesques, natural men and primitives. The dancing figures hover between female and savage: they wear skirts and feathers, signifiers of a 'feminine and lower-class predilection for decorating their bodies' (McClintock 1995, p.224); at the same time the Aborigines brandish weapons in both hands, so evoking a physical danger intensified by the youth of the boys and their lack of protection. The central contrast, though, is between rational, thoughtful, controlled boy observers and wild, irrational, adult Aborigines, and this opposition, between white boys and Aboriginal adults, constitutes one explanation for the absence of Aboriginal children: that is, that they are redundant; the category 'child' is occupied by that of 'Aborigine', so that Harry and Donald, like many focalising boy heroes, prove themselves to be men through their encounters with childish Aborigines.

Such an identification of 'child' with 'Aborigine' constitutes what Johannes Fabian has termed a 'denial of co-evalness' (in Mills 1991, p.48), the mobilisation of discourses of temporality to consign colonised races to a primitive and backward state; as Fabian says, 'Time...is a carrier of significance, a form through which we define the content of relations between the Self and the Other' (Mills, p. 89). Australian colonial texts for children display particular inflexions of this discursive strategy, drawing first on the idea of the Great Chain of Being and later the tenets of Social Darwinism to represent Aborigines collectively as fixed in a perpetual childhood at the bottom of the hierarchy of races, and individual Aborigines as incapable of progressing from childhood to adulthood. But in texts for children, the collapsing of 


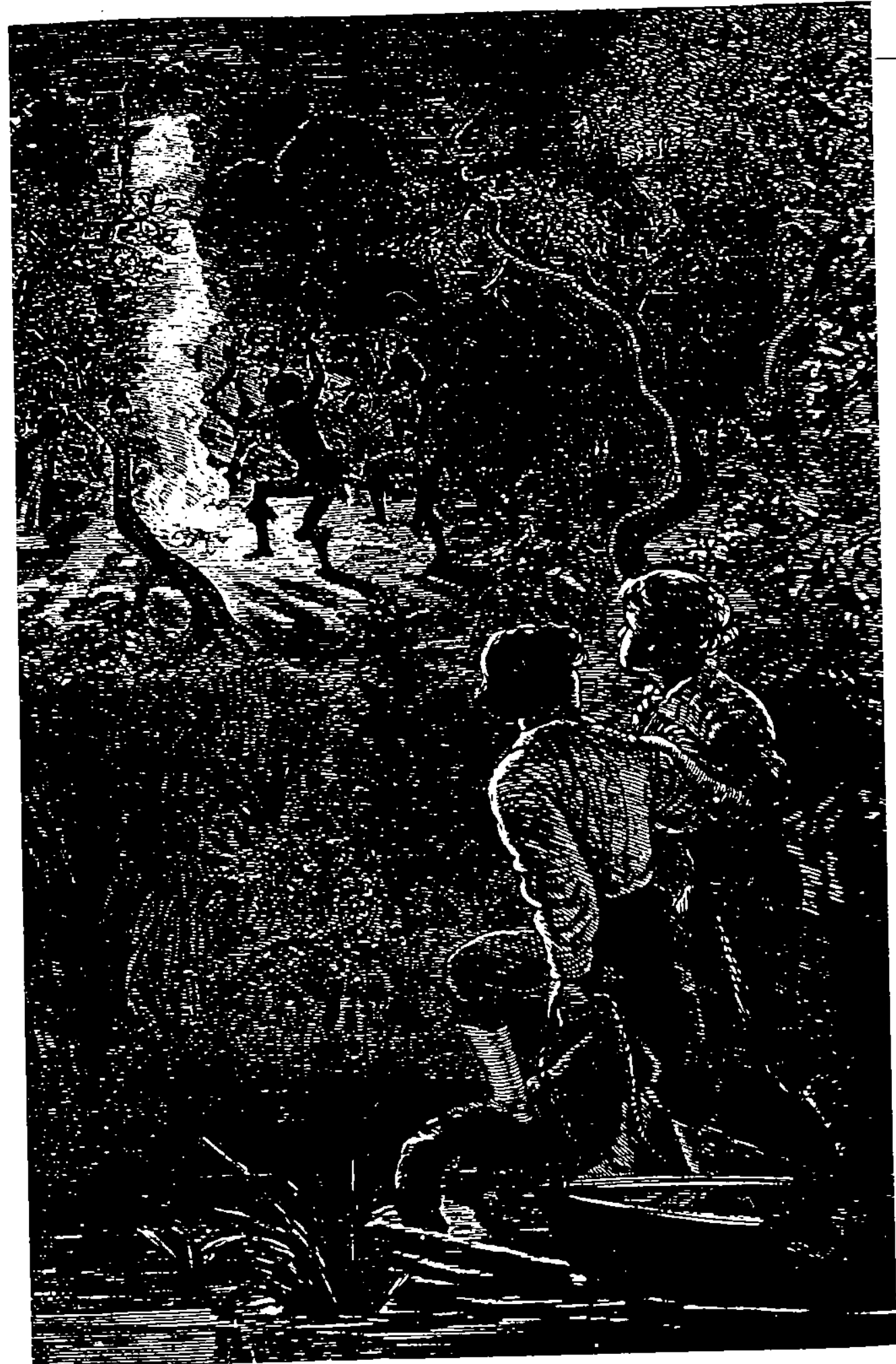

Plate 1 
the categories 'child' and 'Aborigine' work in a peculiarly potent way, for their focalising characters and their implied readers are imagined as children who are in the process of becoming adults, whereas the adult Aborigines who feature in the texts are perpetual children; not, like Peter Pan, projections of adult nostalgia and desire, but manifestations of imperial ideologies which position other nations negatively in relation to a British norm.

An illustration from W.H.G. Kingston's Twice Lost (1881) (Plate 2), exemplifies the indigenous-as-child trope; it also displays the homogenisation of non-English races within imperial discourse, since the Aborigine Pullingo is a universalised black man, represented against vegetation which is, broadly speaking, exotic (Kingston was, after all, the imperial novelist par excellence, producing over a hundred adventure novels set in all parts of the British Empire). Provided with a pair of trousers, Pullingo is at first charmed by their novelty, but then progressively irritated by their restrictiveness. The illustration's insistence on the incongruity of black body and white trousers encodes an epistemological clash: Pullingo's rejection of clothing discloses his failure to understand what clothes mean: civilisation, propriety and order. His capering figure thus becomes a ludic spectacle, a joke for white children. Generally, figures who look directly from a picture 'demand an imaginary social response of some kind from the viewer' (Kress and van Leeuwen 1996, p.124); in this instance, however, Pullingo is the object and not the subject of the look, because the colonial man at the back left of the picture models how Pullingo is to be looked at: kindly, condescendingly, as adult to child. The body of colonial man in this picture is covered by the accoutrements of an imperial uniform; in contrast, Pullingo's bare body and his boldness in directly addressing the viewer slips into a pattern of representation common in nineteenth-century texts, one in which Aborigines are subject to the "colonial

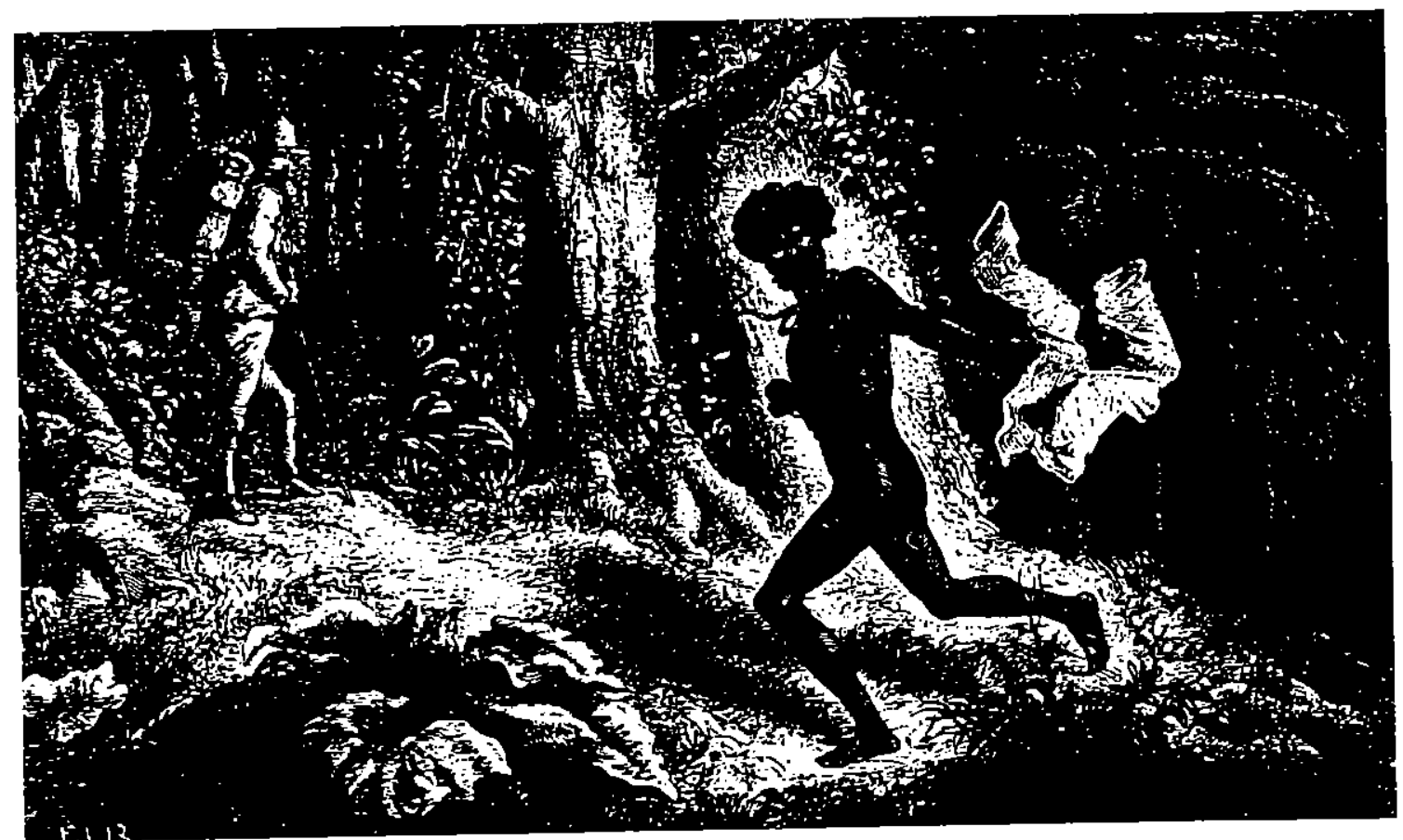

Plate 2 
ambivalence' identified by Homi Bhabha (in McClintock 1995, p.404). First, they are defined as objects by their colour; and second, when they are required to mimic their colonial masters (in this case through the symbolic means of clothing) they expose the gap between themselves and colonial man, being flawed and imperfect images of colonials. Child readers of this illustration are thus positioned to see Pullingo as object and eternal child; moreover, as wilfully rejecting the advantages of civilisation.

In The Water-Babies, Tom is especially outraged by the appearance of the 'little black ape' in Ellie's white bedroom, a space marked both for class and for gender; similar boundaries manifest within colonial texts in the distinction between 'home' and 'the bush'. The homesteads from which colonial boys depart and to which they return after their adventuring constitute centres of feminine order: safe havens where mothers and sisters exercise their civilising and spiritual influence. Aboriginal children are rarely depicted within these domestic settings, but belong to the spaces outside the home, the far more dangerous realm where colonial boys undertake adventures. Nor do Aboriginal children feature when white boys engage in armed conflict with Aborigines, since boy adventurers are constructed as heroes through being vastly outnumbered, and through unequal conflict with Aboriginal men. In adventure novels, then, the principal category into which Aboriginal children fit is that of servant boys: either good or bad.

The Aboriginal boy as good servant is a figure of considerable longevity in Australian children's texts, surviving from the nineteenth century into the middle of the twentieth: Black Billy, having first appeared in $A$ Little Bush Maid (1910), is still an elderly boy in 1942, in Billabong Riders. These boy servants are indeterminate of age, since, as I've said, they are in any case perpetual children. But references to their childishness appear in collocational clusters alongside terms such as 'greedy', 'fickle' and 'cowardly', and so the sign 'child' as applied to Aboriginal boys is very different from its application to the white boys on whom these narratives centre, whose 'childishness' is framed as a developmental stage. Indeed, white boys, while often represented as rash or even foolhardy in their appetite for adventure, are generally shown to perform tasks and feats which are strictly speaking beyond them: which belong, rather, to a world of white heroic men.

Like Black Billy of Billabong, the Aboriginal boy servants in settler and adventure narratives are strangely isolated, inserted into the culture of sheep or cattle station but never part of the inner circle of settler family and friends, and without parents or kin of their own. I suspect that this feature can be explained partly by ignorance, on the part of authors of these texts, of Aboriginal kinship systems and sociality; but it also serves to occlude those stories of white violence upon Aboriginal people which might be required in order to explain how Aboriginal boys came to be servants of white families. The names they are given within these narratives fall into three clusters: quasiAboriginal names such as Murri, Kooli and Hookey; conventional British names, Mickey, Jimmy, Harry and Billy; and names with ironic overtones, such as Prince Chummy (son of King Dick-A-Dick), Sambo, Pinkie and Prince Tom. Compared with the stout British names of boy heroes such as Alec and George Law, Harry Lawson, Rowley Darvall and Paul Berrington, these half-names encode otherness and lack; without patronymics or clan names, they read as contingent and arbitrary, invoking a comic or pathetic dissonance between signifier and signified. The name 'Prince Chummy', for example, encodes both unprinceliness and the cultural chasm between the character Chummy and the Boys' Own associations of the term 'chum'.

One of the narrative functions of Aboriginal servant boys in adventure novels is as comic relief or not-very-wise fool, but the ideological underpinning of this figure involves a set of contrasts which serves to reassure child readers of the boundaries between 'us' and 'them'. Such ideologies are obvious in the following excerpt, from Alfred St Johnston's In Quest of Gold, or Under the Whanga Falls (1885), in which adolescent brothers, George and Alec Law, undertake a search for the gold nuggets which lie beneath a waterfall far from their property. Here, Alec and George and their two Aboriginal servants, Murri and Prince Tom, leave the homestead to embark on their quest: 


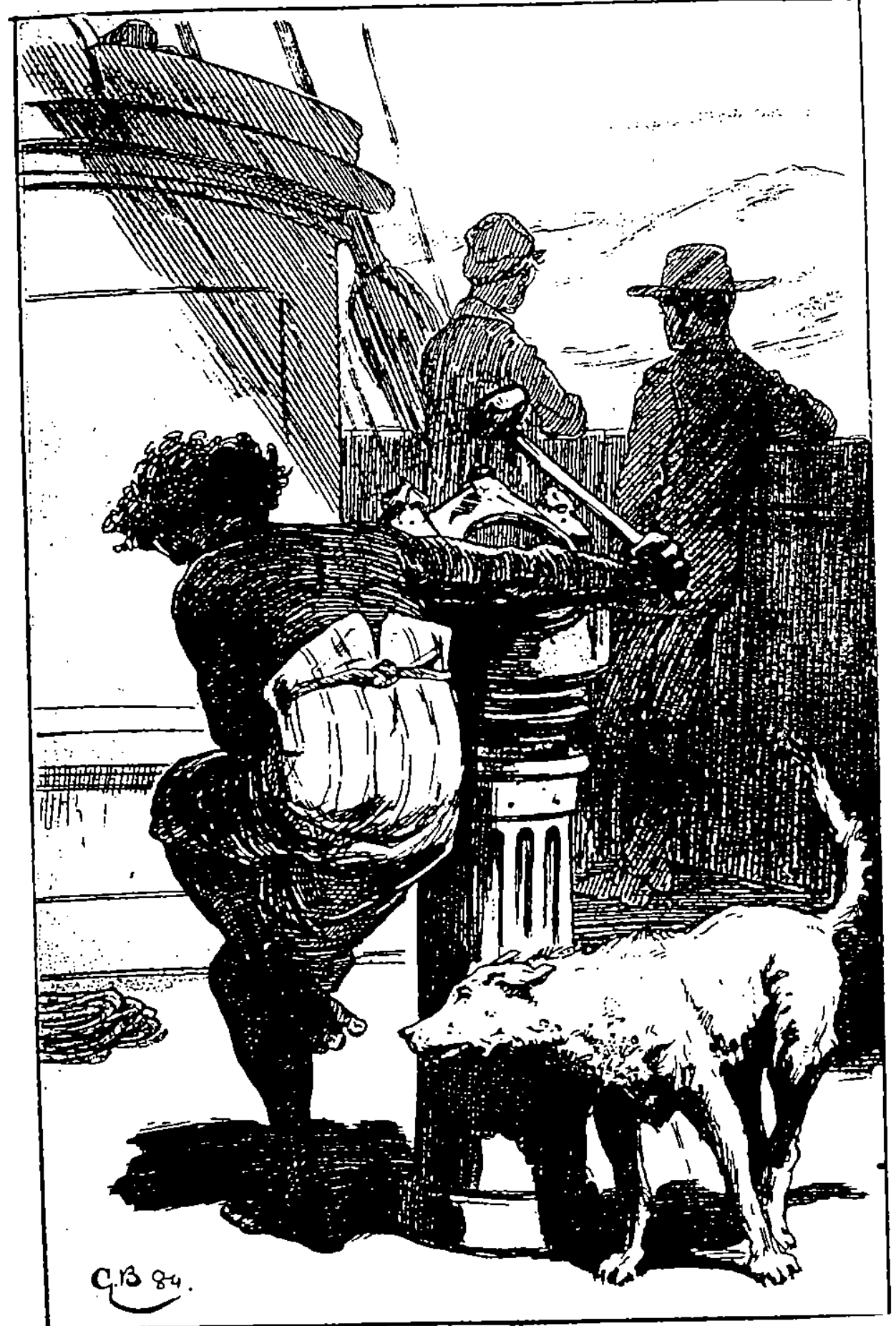

Plate 3 


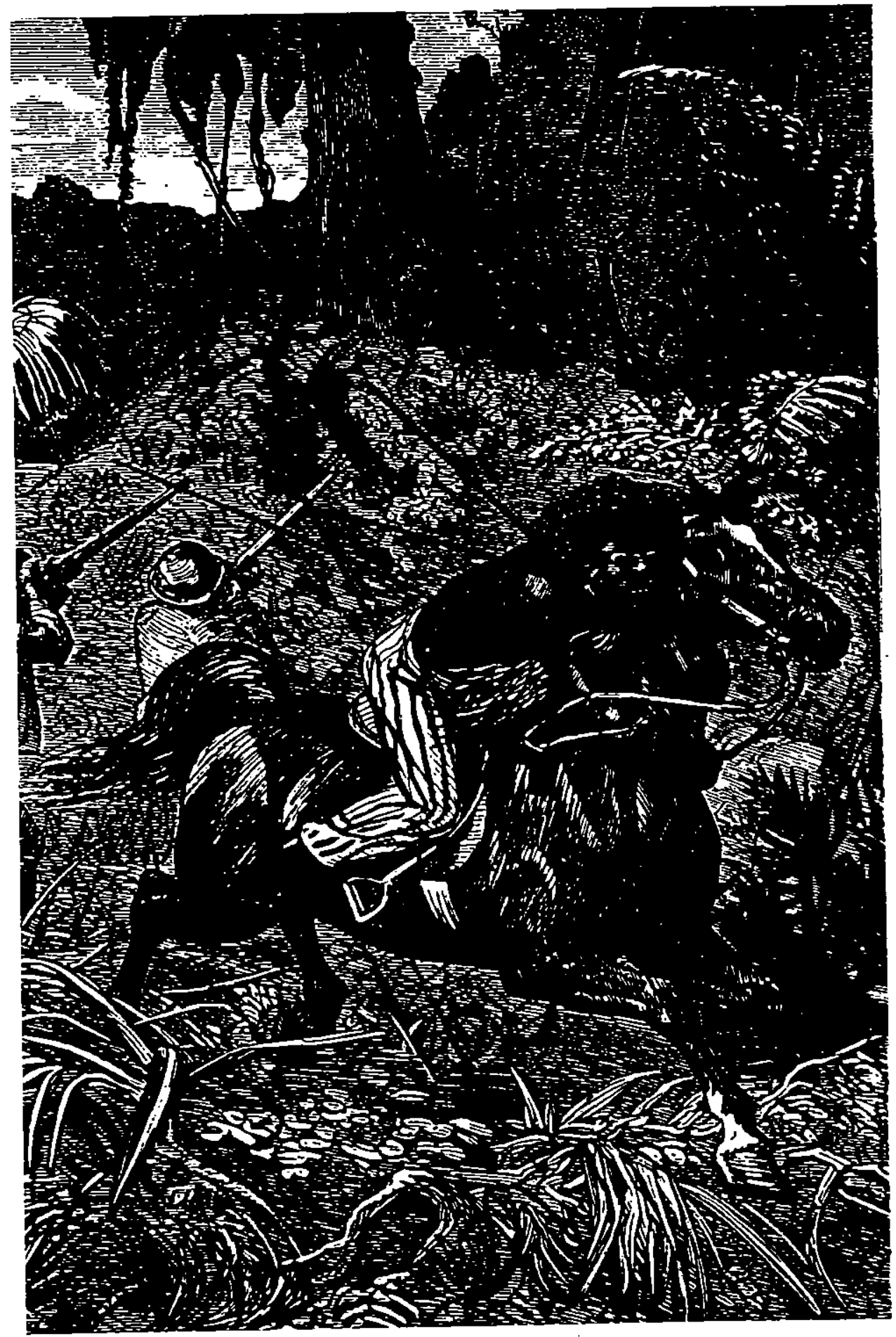

Plate 4 
Chummy's death is of course treated as unheroic - he's speared in the back while attempting to escape his pursuers - but what is more significant is the illustration's focus on the moment of his death: his eyes, fixed on a point out of the frame, don't directly address the viewer but construct Chummy as the 'object of dispassionate scrutiny' (Kress and van Leeuwen, p. 124). His foregrounded figure relates through a vertical axis to the 'wild blacks' above him, so constituting him as hybrid grotesque; linked by blackness to the grotesque Others, but visually aligned with the white boys by his clothing and by the horse he rides. His death, then, embodies a projection of colonial anxiety about boundaries, and reasserts for the child reader those distinctions between white and black which are so destabilised by the hybrid grotesque. Harry and Donald are again constructed as 'little men', heroes stoutly defending themselves against the savage horde; and the imbalance of guns to spears and clubs is displaced visually by way of another reminder of savagery: the spears protruding from Chummy's body and criss-crossing the lines of the boys' weapons.

Although there are a number of colonial novels in which white boys befriend childlike black adults, there are few in which white and black children are represented as allies or friends. A bizarre and interesting exception is Herbert McIlwaine's turn-of-the-century novel The White Stone (1900), in which Rowley Darvall, a boy living on a remole cattle station, is on intimate terms with an Aboriginal boy, Pinkie, although their friendship is scarcely one of equals (Plate 5). The depiction of the relationship of Rowley and Pinkie is informed by tension concerning another peril associated with boundaries: that of the white boy 'going native':

These two had been companions almost since their babyhood, and were knit in so close an intimacy that, really and in truth, each was a part of the other-each impressed the other with that which was strongest in himself. Thus, the nigger blindly worshipped and obeyed the white boy because he had the brains and skill and courage of a superior race; but the white boy came to share the conviction of the black one - because it was as strong in him as life itself - that, by night. the earth and air were peopled by frightful creatures that should tear them limb from limb if they went out alone and without a burning firestick in their hands, into the darkness.

(p.84)

The two boys running from the Rackhamesque spectres (Plate 6) are equally wild-eyed, but Pinkie, feminised by the white shift he wears, is a ludic figure blundering towards the viewer, while Rowley's movement plots a more purposeful direction from right to left.

To circumvent the danger of Rowley's 'going native', he is sent 'home' to a boarding school in England; his mother says, '...The bush, and Pinkie, and the animals and the open air, they're in his blood, ...too deeply to let him grow up the man that we're to be proud of in our old age' (p.30). Rowley is re-formed as an Englishman through cricket, his success as a fast bowler enacting his recovery of his white self. In the meantime, Pinkie almost dies because of his fretting for Rowley, but is saved when Rowley sends him a message-stick assuring him that he is alive and well. The closure of The White Stone restores the colonial hierarchies through Pinkie's heavily symbolic acl of obeisance as Rowley returns to Australia, thoroughly Anglified, to take over as master of the family property:

...there was a pattering of naked feet on the path. afall among the dead leaves, and Rowley's knees were locked in the embrace of Pinkie, who was looking up at his master and saying, over and over again, 'Rowlee come back now long big water!'

(p.373)

The novel's closure proposes a model of Australian nationalism based on Englishness, but the anxiety produced by the idea of hybridisation finds its expression in a contradictory see-sawing between repulsion and attraction. The wild playfulness of the two boys, and their attachment to each other, are the liveliest part of the book, escaping the formulaic and melodramatic patterns of its narrative following Rowley's departure for England. In this way The White Stone displays with particular clarity the predicament of a writer located within the discursive framework of colonialism, but to whom the 'illusion of a 
stable self/other, here/there binary division' (Slemon 1995, p. 109) is unavailable. This is not to suggest that The White Stone is an anti-colonial text; on the contrary, it strenuously and overtly promotes the colonial project; but its depiction of Pinkie and of the seductiveness of hybridity is resistant to the binaries of colonial discourse.

Finally, I'll discuss two texts which afford early examples of a phenomenon common in Australian texts of the first half of the twentieth century, which Hodge and Mishra, following Said, term 'A boriginalism' (Hodge and Mishra 1990 , pp. 27-30), the textual sleight-of-hand whereby white authors and scholars profess sympathy with Aboriginal interests and fascination with Aboriginal narratives and cultural practices, while at the same time insisting on speaking for Aborigines and claiming the right to interpret their utterances and their narratives. The double movement of Aboriginalism typically works through textual practices which appear to construct Aboriginality in the most benign of terms, while simultaneously inscribing Aborigines as primitives, objects of white protectiveness, incapable of assuming agency in their own interests, locked into a mythical past outside time.

Aboriginal children are awkwardly positioned within Aboriginalist discursive regimes, because they symbolise a future which is at odds with the representation of Aborigines as embodiments of a primitive past. Children of mixed race are particularly problematic, since they symbolise both futurity and a fluidity of identity inscribed as impure or inauthentic.

Mary Fitzgerald's 1891 collection of stories, King Bungaree's Pyalla, includes a story entitled 'Kirrick the

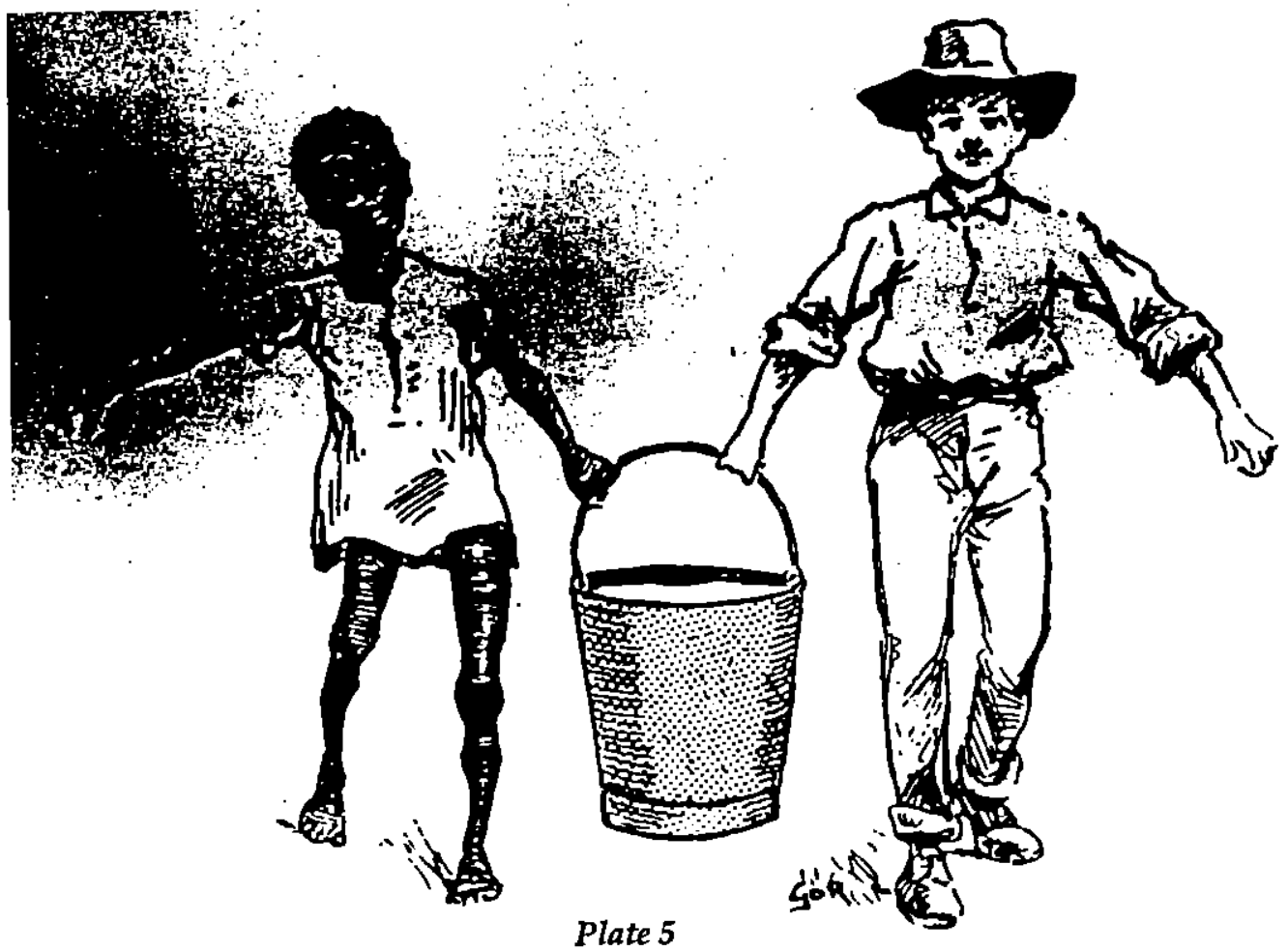




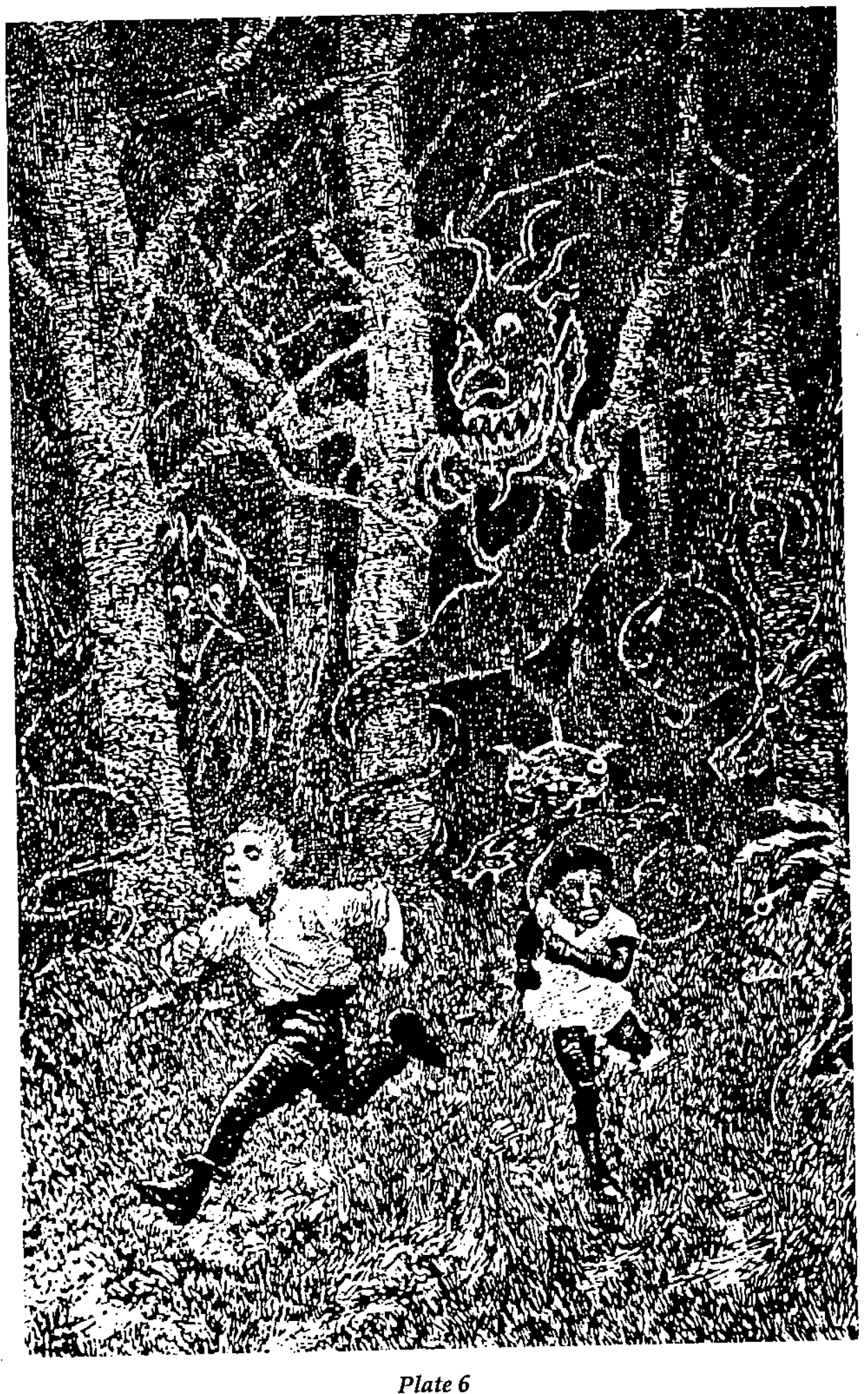


Half-caste', in which the Glay'den children, living on a sheep station, make friends with Kirrick, whose mother is said to be a 'tall slender young blackwoman, with a sad quiet face' (p.64). Her white father is the master of a neighbouring property, and here the text's disclosure of his identity is equivocal and guarded, strangely (and probably strategically) attributed to Jacky, the Glayden's 'station black', who claims that Kirrick resembles 'the picture hanging in the hall at Bella station, far more than the master, for whom it was intended' (p.62). Kirrick's white ancestry, which raises her above the level of her Aboriginal mother, is reminiscent of the schema, in Western folktales, in which characters are removed by magic or human intervention from their aristocratic origins, an association heightened by the misogynist explanation of the Glayden boys, who surmise that Kirrick "must have had a cruel stepmother, who sent her away to live with the blacks, like poor Blue Bell, who lived with dwarfs in the mountains' (p.62); such blaming of the cruel stepmother serves, of course, to occlude the guilt of Kirrick's putative father.

Whereas the folktale schema of the disenfranchised heiress or heir is resolved by the restoration of the child to its rightful home and setting (and marriage to a prince or princess), the story of Kirrick adheres to no such comfortable pattern. She becomes a favourite of the Glayden family, displaying her genetic superiority by her musical ability and physical beauty: there is ' an expression of extreme sweetness in the timid little face, around which clustered in careless beauty, a profusion of dark curling hair, so unlike the hsir of the aborigines, which is generally coarse and lank' (p.63). The Glaydens give her a white dress, which she wears while searching for bush food when her clan leaves the station, but it's this dress, the marker of her hybridity, which kills her:

There lay the body of the half-caste child robed in the same white frock, which had, in becoming entangled in the mangrove branch, no doubt been the cause of her death, for no water bird can swim better than the aboriginal children.

(p.69)

This narrative insistence on the morbidity of children of mixed race maps one strand of the widespread preoccupation, in popular and political discourses of the nineteenth and early twentieth centuries, with what was frequently called 'the half-caste problem' (McGregor 1997, pp.134-141), white paranoia about the possibility that the nation would be populated by people of mixed race. While Mary Fitzgerald's oblique eriticism of Kirrick's father distinguishes the story of Kirrick from the harsher judgments made of Sally's mother in $A$ Mother's Offering, it's nevertheless the case that the child's death is, in a similar way, naturalised as fitting and appropriate. But Kirrick's death also carries broader significances, which relate to Mary Fitzgerald's introduction to King Bungaree's Pyalla, in which she dedicates the book to

... the Girls and Boys of my Native Country... hoping it may interest them in the Folk-lore of that simple people, now fost expiring. but who were once lords of this glorious land.

For the death of Kirrick metonymically represents the disappearance of 'that simple people', and disposes of Aboriginality altogether, effecting a displacement through which white children, represented by the Glaydens, become the new 'Jords of this glorious land'. And the worthiness of the Glayden children to assume ownership of Kirrick's land is invoked through their action in placing at the scene of her death an inscription: 'Here Lies Our Dear Kirrick Drowned' (p.70).

The final text to which I'll refer is one of the most influential Aboriginalist texts for children, Kate Langloh Parker's Australian Legendary Tales (1896). This collection, republished many times and as recently as 1978, is introduced by Andrew Lang and includes 'illustrations by a native artist, and a specimen of the Native Text'. Dedicated to 'Peter Hippi King of the Noongahburrahs', it shares with many later texts what Brenda Niall terms 'the...authorial attitude... of memorialist' (1984, pp.213-214), focussing on an Aboriginality fixed in a distant past:

There are probably many who, knowing these legends, would not think them worth recording; 
but, on the other harc licpe there are many who think, as I do, that in sizld try, while there is yel time, to gather $c=0$ imation possible of a race fast dying ou: $= \pm$ origin of which is so obscure.

(p.ix)

This classic Aboriginais $=$ ment both affirms and denies the value of Abct narratives by noting the low opinion in which ' $52-5$ ' for the collector a refiecer irtue derived from her concern for the survival $=5=5$ in danger of extinction

Parker claims a further $c=-5 \mathrm{~s}=\mathrm{s}$ of significance through her invocation of chili $=-5$, both Australian and British:

Though / have writter $7:=$ book in the interests of folk-lore, I hope $\vdots$ gain the attention of, and have some intere- icr. sildren-of Australian children, because ita? find stories of old

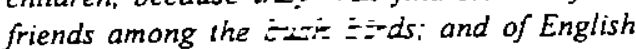
children, because I incte $=\bar{z}$ they will be glad to make new friends, $\sigma c_{1}: z s r a b l i s h$ a free trade between the Austrai: $=-$ English nurseries wingless, and laugris in exchange for fairy god-mothers, cacis in disguise. (pp.x-xi)

The (white) children her - jcsisined as the book's readers are offered Aboriginal rases either as stories of the

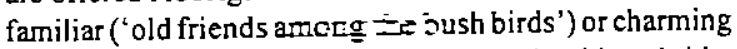
novelties ("new friends"j. Dopite the book's subtitle, 'Folk-Lore of the Nocrgezrahs as Told to the Piccaninnies', the Aborild =ildren who constituted the putative audience c carratives appear not as characters or implied hez=s only as shadowy figures sitting around their car $=$. the objects of Parker's benevolence:

I can only hope that ise... xle of this booklet be such as to enable me ic frocks and tobacco when I give their Cry dinner, as is my yearly custom, io :-2 remnant of the Noongahburrahs

(p.x)
Nor, despite Parker's transcription of Noongahburrah language and her provision' of a glossary, is there any reference to the cultural practices within which the narratives belonged, the dynamics of their telling, the relationships between teller and audience, the country of their production. The stories appear, then, as disembodied fragments, melancholy reminders of the children to whom they were told.

This sense of melancholy concerning 'a race fast dying out' marks a site of slippage in Aboriginalist discourse, around notions of cultural and textual purity. Aboriginalist reading regimes insist that the category 'Aborigine' is constituted by 'full-blooded' Aborigines living in traditional settings, and such a construction of 'pure' Aboriginality, common at the time Parker published the Noongahburrah narratives, throws onto the white collector the onus of speaking for Aborigines who are assumed not to be able to speak for themselves. This appropriating move constructs a power relationship in which Aboriginalism stands between Aborigines and white readers, mediating for the latter its exclusive access to the former. What the apparent benevolence of Aboriginalism displaces, however, is its inability to believe in the resilience and adaptability of Aboriginal culture; and this is why the figure of the Aboriginal child is so problematic to Aboriginalism. It's impossible to miss the contempt in what Parker says about young Aborigines, who in her terms are tainted by modernity:

The time is coming when it will be impossible to make even such a collection as this. for the old blacks are quickly dying out, and the young ones will probably think it beneath the dignity of their so-called civilisation even to remember such oldwomen's stories.

(p.ix)

In Imagined Destinies: Aboriginal Australians and the Doomed Race Theory (1997), Russell McGregor notes that 'for the majority of colonial commentators there appears to have been something irresistibly attractive in the notion of inevitable Aboriginal extinction' (p.14). A 
similar attraction can be seen in the texts I've discussed. The Aboriginal children of these narratives carry a range of significances: as figurés of Otherness; as hybrid grotesques; as displacements of white guilt; as metonyms of a dying race. Most of all, these texts offer white child readers absolution from colonial guilt, by naturalising the deaths of individual Aboriginal children, and of Aborigines collectively. But the very obsessiveness with which they link death and Aboriginal children, and the gaps and ruptures visible in their representations of these children, disclose their anxiety about racial purity and about the legitimacy of Australian nationhood. The outcome most feared and dreaded is one in which the white child looks at the Aboriginal child and, like Tom in The Water-Babies, sees his ow'n tikeness.

\section{REFERENCES}

A Mother's Offering to Her Children by A Lady Long Resident in New South Wales (1841, facs. ed. 1979). Sydney, Jacaranda Press.

Attwood, Bain (1992) 'Introduction', in Attwood, B., and John Arnold, eds., Power, Knowledge and Aborigines. Melbourne: La Trobe University Press.

Dixon, Robert (1995) Writing the Colonial Adventure: Race, Gender and Nation in Anglo-Australian Popular Fiction, 1875-1914. Cambridge: Cambridge University Press.

Donald, James (1988) 'How English is it? Popular literature and national culture', New Formations 6 , pp. 31-47.

Fenn, G.Manville (1885) Bunyip Land. Glasgow, Edinburgh and Dublin, Blackie \& Son.

Fitzgerald, Mary Anne (1891) King Bungaree's Pyalla and Stories Illustrative of Manners and Customs That Prevailed Amongst Australian Aborigines. Sydney, Edwards, Dunlop.

Foucault, Michel (1971, repr. 1989) 'The Order of Discourse', in Rice, Philip and Waugh, Patricia, eds., Modern Literary Theory: A Reader. London: Arnold.
Foucault, Michel (1972) The Archaeology of Knowledge. London: Tavistock.

Hodge, B. and Mishra, V. (1990) Dark Side of the Dream: Australian Literature and the PostColonial Mind. Sydney: Allen \& Unwin.

Kincaid, James R. (1992) Child-Loving: The Erotic Child and Victorian Culture. New York: Routledge.

Kingsley, Charles(1958) The Water-Babies. London, Dent (1863).

Kingston, W.H.G. (1878) Twice Lost. London, T. Nelson and Sons.

Kress, Gunther and van Leeuwen, Theo (1996) Reading Images: The Grammar of Visual Design. London: Routledge.

McClintock, Anne (1995) Imperial Leather: Race. Gender and Sexuality in the Colonial Contest. New York: Routledge.

McGregor, Russell (1997) Imagined Destinies: Aboriginal Australians and the Doomed Race Theory, 1880-1939. Melbourne: Melbourne University Press.

Mcllwaine, Herbert (1900) The White Stone. London, Wells Gardner, Darton \& Co.

Mills, Sara. Discourses of Difference: An Analysis of Women's Travel Writing and Colonialism. London: Routledge, 1991.

Muir, M. and White, K. (1992)Australian Children's Books: A Bibliography, vol.l 1742-1972, vol.2 1973-1988. Melbourne: Melbourne UP.

Niall, B. (1984) Australia Through the Looking Glass: Children's Fiction 1830-1980. Melbourne: Melbourne UP.

Parker, K.Langloh (1896) Australian Legendary Tales. London, Nutt.

Reynolds, Henry (1987) Frontier: Aborigines. Settlers and Land. Sydney: Allen \& Unwin. 
Rowe, Richard, as Edward Howe (1869) The Boy in the Bush. London, Bell \& Daldy.

Scholefield, Mrs. H. (1853) A Short Memoir of William Wimmera. Cambridge.

Slemon, Stephen (1995) 'Unsettling the empire: Resistance theory for the second world', in Ashcroft, Bill, Griffiths, Gareth and Tiffin, Helen, eds., The Post-Colonial Studies Reader. London: Routledge, pp. 104-113.

St.Johnston, Alfred (1885) In Quest of Gold; or, Under the Whanga Falls. London, Cassell \& Company.

Stallybrass, Peter, and Allon White (1986) The Politics and Poetics of Transgression. London: Methuen.

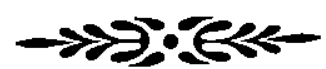

\section{BIOGRAPHICAL NOTE}

Clare Bradford is an Associate Professor in the School of Literary and Communication Studies at Deakin University, where she teaches children's literature and literary studies, and supervises students undertaking research degrees. Her main research interests are in postcolonial theory and literature, picture books and contemporary Australian texts. She has published many journal articles and book chapters; her most recent book is Writing the Australian Child (1996). She is currently the President of the Australasian Children's Literature Association for Research.

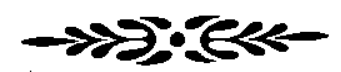

